\title{
INFLUENCE OF Urochloa brizantha ON THE GROWTH AND NUTRITIONAL ABSORPTION OF TREE SPECIES
}

\author{
João Elves da Silva Santana ${ }^{1}$, Paulo Sergio dos Santos Leles ${ }^{* 1}$, Alexander Silva de Resende ${ }^{2}$, Monique \\ Muniz Monteiro Dias ${ }^{1}$, Daniel Fonseca de Carvalho ${ }^{3}$, Thales Costa de Lima ${ }^{1}$ \\ 1* Universidade Federal Rural do Rio de Janeiro, Departamento de Silvicultura, Seropédica, Rio de Janeiro, Brasil - joao- \\ elvis@outloook.com,psantosleles@gmail.com*, munizmonique29@hotmail.com, thales_costa10@yahoo.com.br \\ ${ }^{2}$ Embrapa Agrobiologia, Seropédica, Rio de Janeiro, Brasil - alexander.resende@embrapa.br \\ ${ }^{3}$ Universidade Federal Rural do Rio de Janeiro, Departamento de Engenharia, Seropédica, Rio de Janeiro, Brasil - \\ daniel.fonseca.carvalho@gmail.com
}

Received for publication on: 28/06/2018 - Accepted for publication on: 03/06/2020

\section{Resumo}

Influência de Urochloa brizantha sobre o crescimento e absorção nutricional de espécies arbóreas. Objetivouse avaliar a influência da convivência de Urochloa brizantha var. Marandu sobre o crescimento e acúmulo de macronutrientes nas folhas de Cordia trichotoma e Guarea guidonia. Mudas das espécies arbóreas foram transplantadas em vasos de 18 litros e mantidas livres da braquiária durante três meses. Após esse período, foram adotados três tratamentos que consistiram da testemunha (T0), duas plantas de braquiária (T2) e quatro plantas de braquiária por vaso (T4). Foram avaliados o crescimento e o acúmulo de nutrientes das espécies arbóreas após 84 dias de convivência com a braquiária. $\mathrm{O}$ incremento em diâmetro, de ambas as espécies arbóreas, área foliar e massa de matéria seca da parte aérea de G. guidonia foram afetados de maneira significativa pela presença de $U$. brizantha, em relação à testemunha. Foram observadas diferenças significativas para o acúmulo de potássio e magnésio nas folhas de C. trichotoma.
\end{abstract}

Palavras-chave: matocompetição, crescimento de espécies arbóreas, Cordia trichotoma e Guarea guidonia

\begin{abstract}
The objective of this study was to evaluate the influence of Urochloa brizantha var. Marandu on the growth and accumulation of macronutrients in the leaves of Cordia trichotoma and Guarea guidonia. Seedlings of tree species were transplanted to 18 -liter pots and kept free of $U$. brizantha for three months. After that period, three treatments were adopted that consisted of the control (T0), two plants of $U$. brizantha per pot (T2) and four plants of $U$. brizantha per pot (T4). Growth and nutrient accumulation of tree species were evaluated after 84 days of coexistence with $U$. brizantha. The increment in diameter, of both tree species, leaf area and shoot dry matter of G. guidonia were significantly affected by the presence of $U$. brizantha, compared to the control. Significant differences were observed for the accumulation of potassium and magnesium in the leaves of $C$. trichotoma. Keywords: weed competition, growth of tree species, Cordia trichotoma and Guarea guidonia.
\end{abstract}

\section{INTRODUCTION}

Forest restoration projects with planting of tree seedlings usually have high costs (TRENTIN et al., 2018), and a significant part of these is related to weed management activities. In the Southeast region of Brazil, most of the degraded areas are occupied by abandoned or poorly used pastures, with predominance of grass species, such as palisade grass - Urochloa sp. (RESENDE and LELES, 2017), which are the most cultivated forage species in South America and support a large portion of the national cattle herd (MARCHI et al., 2017). These are highly adapted to high light conditions (ZHONG et al., 2018), showing high capacity to acquire and convert resources such as light, water and nutrients (HALING et al., 2013).

Even with species well adapted to tropical conditions, inadequate management of pasture areas favors the occurrence of degradation processes (FONTE et al., 2014), so these areas are no longer able to support the animal feeding and are abandoned. Therefore, these areas end up being the places destined to meet the requirements of environmental legislation, such as forest restoration projects from the formation of stands with native tree species.

Due to the relatively wide spacing between the planting "rows" and the low soil cover by the canopy of the plants, in the first stages of stand establishment (VASIC et al., 2012), the planting areas can favor the growth and development of grasses, such as $U$. brizantha, hindering the restoration process. Thus, tree species that have relatively slow growth need to compete for resources with species that are already adapted in the area. Therefore, in order to optimize control strategies, such as the use of mechanical, chemical and cultural techniques, it is necessary to understand how tree species behave in the presence of weed species.

FLORESTA, Curitiba, PR, v. 50, n. 4, p. 1725 - 1730, out/dez 2020.

Santana, J. E. S. et.al.

ISSN eletrônico 1982-4688

DOI: $10.5380 /$ rf.v50 i4. 60174 
Studies on the influence of weed competition with Eucalyptus sp. plants are well reported in the literature (SILVA et al., 2004; PEREIRA et al., 2011; MEDEIROS et al., 2016). However, information on the responses of Atlantic Forest tree species to competition with weeds is still incipient, as highlighted by Santos et al. (2019a).

The tree species of occurrence in the Atlantic Forest are usually sensitive to the interference imposed by the coexistence with grasses, during their initial growth, which includes the period from planting to about two to five years of age, depending on the quality of the site (RESENDE and LELES, 2017), and such competition can result in reduced growth of trees (SANTOS et al., 2019a).

According to Pitelli (1985), several factors affect the magnitude of interference, such as the planted species, weed species and environmental factors. In addition to these factors, according to Colmanetti et al. (2019), there is also weed density. In this context, studies on the behavior of tree species in the presence of weeds are important to generate information that allows to perform weed control more efficiently, with more appropriate practices of control and used at the most appropriate time for each situation (SWANTON et al., 2015), including the identification of native tree species with greater potential for competition with the species of the genus Urochloa.

The objective of this study was to evaluate the effects of Urochloa brizantha interference on the initial growth and macronutrient concentration in the shoots of Cordia trichotoma and Guarea guidonia.

\section{MATERIAL AND METHODS}

\section{Experiment characterization}

The study was carried out in the experimental field of the Brazilian Agricultural Research Corporation (Embrapa - Agrobiology), located in the municipality of Seropédica, RJ, Brazil (2245’18,42”S, 4340'4,41' W). According to data collected at the meteorological station of INMET (Agricultural Ecology), during the study (June to December 2017) the average monthly rainfall was $60 \mathrm{~mm}$, with a period of lower rainfall between July and September and with a higher incidence of rainfall between October and December. The average temperatures were $22,6^{\circ} \mathrm{C}$, with a maximum of $38,3^{\circ} \mathrm{C}$, recorded in November, and a minimum of $11,3{ }^{\circ} \mathrm{C}$ in August.

Seedlings of two tree species of occurrence in the Atlantic Forest, Cordia trichotoma (Vell.) Arráb. ex Steud. (Louro-pardo) and Guarea guidonia (L.) Sleumer (Carrapeta), were produced in plastic bags with dimensions of 9,7 x 20,0 cm (diameter x height). The competing species used was Urochloa brizantha (Stapf) Webster cv. Marandu.

The experiment was conducted in pots with capacity of 18 liters, with upper diameter of $30 \mathrm{~cm}$, lower diameter of $25 \mathrm{~cm}$ and height of $28 \mathrm{~cm}$. The substrate used was a mixture of Argissolo Amarelo (Ultisol) and sewage sludge (biosolids), in a volumetric ratio of 9:1. The fertility analysis of the substrate used showed the following results: $\mathrm{pH}=5,8 ; \mathrm{P}=146 \mathrm{mg} \mathrm{dm}^{-3} ; \mathrm{K}^{+}=91 \mathrm{mg} \mathrm{dm}{ }^{-3} ; \mathrm{Ca}^{2+}=6,1 \mathrm{cmol}_{\mathrm{c}} \mathrm{dm}^{-3} ; \mathrm{Mg}^{2+}=1,7 \mathrm{cmol}_{\mathrm{c}} \mathrm{dm}^{-3} ; \mathrm{H}^{2}$ $+\mathrm{Al}=2,3 \mathrm{cmol}_{\mathrm{c}} \mathrm{dm}^{-3} ; \mathrm{CEC}=10,4 \mathrm{cmol}_{\mathrm{c}} \mathrm{dm}^{-3}$ and organic matter content of $3,6 \mathrm{dag} \mathrm{\textrm {kg } ^ { - 1 }}$.

The study began with the transplantation of the 24 seedlings of each species to the pots. Cordia trichotoma and Guarea guidonia seedlings were at 120 and 140 days after sowing and had average height of 68 and $52 \mathrm{~cm}$, respectively.

A completely randomized design was adopted, with three treatments and eight replicates, and the treatments were defined as: T0 - absence of $U$. brizantha plants, T2 - two plants of $U$. brizantha per pot, corresponding to the average density of $U$. brizantha plants in the pasture area, and $\mathrm{T} 4$ - four plants of $U$. brizantha per pot, approximately twice the average density. The number of $U$. brizantha plants was defined from a sampling performed in the municipality of Cachoeiras de Macacu, RJ, Brazil, using a 1 x $1 \mathrm{~m}$ quadrat, randomly placed in the area. The number of plants present in 10 replicates was counted, with an average density of 23 plants per $\mathrm{m}^{2}$.

The pots were kept in full sun and $1 \mathrm{~m}$ apart during the entire experimental period (almost 6 months). In the first three months, the plants of the two tree species were grown without $U$. brizantha, in order to promote adaptation and initial growth of tree species, simulating their establishment in the field, where weeds are previously eliminated, for example by herbicide application or control around the trunk (chemical or mechanical). $U$. brizantha seedlings were grown in trays containing sand and transplanted with about $5 \mathrm{~cm}$ height to the pots of treatments T2 and T4, where they were cultivated together with tree species for more 84 days.

During the entire experiment, other plants species that emerged in the pots were eliminated. From the $U$. brizantha transplanting, the pots were manually irrigated, and soil water content was monitored by the Hydrofarm electronic meter, properly calibrated, with the installation of 3 probes in three pots of the control treatment of each species. From the pots containing the plants, samples were collected with volumetric ring at $0-10 \mathrm{~cm}$ depth to determine soil moisture corresponding to the substrate field capacity. Thus, at each reading, the volume of water to be applied was determined by the following equation:

$$
V I=\{\theta f c-(0,0145 * U-0,0544)\} * Z_{p} * \text { Area }_{p} * 1000
$$

FLORESTA, Curitiba, PR, v. 50, n. 4, p. 1725 - 1730, out/dez 2020.

Santana, J. E. S. et.al.

ISSN eletrônico 1982-4688

DOI: $10.5380 /$ rf.v50 i4. 60174 
where: VI- Volume to be irrigated (L), $\theta f c$ - field capacity of the substrate in the pots $\left(\mathrm{cm}^{3} \mathrm{~cm}^{-3}\right), U$ - Average moisture content $(\%)$ determined by the sensors, $Z_{p}$ - Pot depth $(\mathrm{m})$ and Are $a_{p}$ - Upper area of the pot $\left(\mathrm{m}^{2}\right)$.

\section{Evaluations}

At the time of $U$. brizantha transplanting, measurements of shoot height and collar diameter of the tree plants were taken with a graduated ruler and digital caliper, respectively. Height evaluations were repeated every 21 days, up to 84 days, when the evaluations were completed. In the last evaluation, collar diameter was measured again to obtain the increment in collar diameter (IncCD), and the shoots of the tree plants and U. brizantha were cut, $2 \mathrm{~cm}$ from the pot soil, and separated from the root system. Then, the shoots were taken to the laboratory, where all leaves were removed from each tree plant and analyzed in benchtop LICOR-3600 leaf area (LA) meter. Then, the shoots of the trees, formed by trunk, branches and leaves, as well as the shoots of $U$. brizantha, were placed in paper bags. The root system of the tree species was carefully separated from $U$. brizantha, simultaneously washed in running water, placed to dry on a laboratory bench in the shade for two days and then placed in paper bags.

The shoots and root system were dried in a forced air circulation oven at $65^{\circ} \mathrm{C}$ for 72 hours. After weighing on an analytical scale, the shoot dry mass (SDM) and root dry mass (RDM) of the tree plants were obtained.

After weighing, for each tree species, four plants were selected in each treatment, those with values closer to the average SDM. The leaves of these plants were separately ground and sent to the Plant Tissue Analysis Laboratory to determine nitrogen, phosphorus, potassium, calcium and magnesium contents.

The variances of the growth and nutrient accumulation data were subjected to Bartlett's variance homogeneity test and the residuals had their normality tested by the Shapiro-Wilk test. When the assumptions were not met, the Box-Cox methodology (BOX and COX, 1964) was used to find the appropriate transformation to stabilize or reduce the existing variability and normalize the residuals. Subsequently, analysis of variance and Tukey means comparison test were performed at $95 \%$ significance level.

\section{RESULTS}

Coexistence with Urochloa brizantha did not negatively affect the growth in height of both tree species at the end of the 84 days of coexistence (Figure 1). In the comparison between the first and last evaluation, the increments of height in the treatments were 20,9 (T0), 18,3 (T2) and 17,4 cm (T4) for C. trichotoma and 11,4 (T0), 8,0 (T2) and 8,9 cm (T4) for G. guidonia.
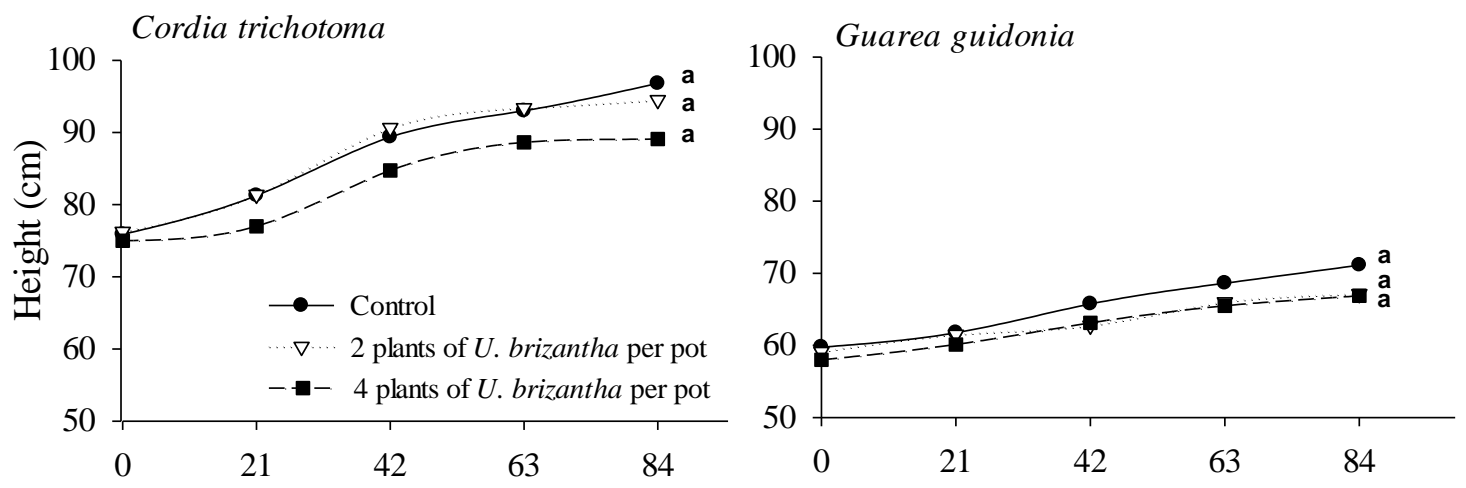

Days after $U$. brizantha transplanting

Figura 1: Valores médios de altura da parte aérea de plantas de duas espécies arbóreas, em convivência com Urochloa brizantha. Testemunha - ausência de plantas de braquiária e 2 e 4 plantas de braquiária por vaso. Para cada espécie, mesmas letras após as curvas de crescimento, indicam que os tratamentos não diferem entre si, quanto ao incremento em altura (0-84 dias), pelo teste de Tukey ( $\mathrm{P} \geq 0,95)$.

Figure 1: Average values of shoot height of two tree species coexisting with Urochloa brizantha. Control - absence of $U$. brizantha plants, and 2 and 4 plants of $U$. brizantha per pot. For each species, the same letters after growth curves indicate that the treatments do not differ from one another for the growth in height $(0-84$ days) by Tukey test $(\mathrm{P} \geq 0,95)$.

FLORESTA, Curitiba, PR, v. 50, n. 4, p. 1725 - 1730, out/dez 2020. 
The increment in diameter (IncCD) of C. trichotoma was significantly affected by the presence of $U$. brizantha, with a significantly higher mean in the treatment with absence of $U$. brizantha (Table 1). For $G$. guidonia, the treatment T0 promoted significantly higher values in ID (44\%), LA (32\%) and SDM (41\%). The SDM/RDM ratio in T4 was about 35\% higher than in T0. For most of the variables of G. guidonia affected by $U$. brizantha, plant in $\mathrm{T} 2$ showed lower growth.

Tabela 1: Incremento em diâmetro do coleto (IncDC), área foliar (AF), massa de matéria seca da parte aérea (MSPA) e do sistema radicular (MSR) de duas espécies arbóreas sob dois tratamentos de convivência, aos 84 dias após semeadura, de Urochloa brizantha e testemunha, em condições de vasos

Table 1: Increment in collar diameter (IncCD), leaf area (LA), shoot dry mass (SDM) and root dry mass (RDM) of two tree species under two treatments of coexistence, at 84 days after sowing of Urochloa brizantha and control, under pot conditions

\begin{tabular}{lccccc}
\hline Tree species & Treat. & IncDC $(\mathrm{mm})$ & AF $\left(\mathrm{cm}^{2}\right)$ & MSPA $(\mathrm{g})$ & MSR $(\mathrm{g})$ \\
\hline \multirow{3}{*}{ Cordia trichotoma } & T0 & $7,2 \mathrm{a}(1,5)$ & $2817 \mathrm{a}(817)$ & $71,8 \mathrm{a}(17,0)$ & $42,2 \mathrm{a}(15,0)$ \\
& T2 & $6,8 \mathrm{ab}(1,8)$ & $2337 \mathrm{a}(525)$ & $73,4 \mathrm{a}(24,0)$ & $57,7 \mathrm{a}(12,1)$ \\
& T4 & $4,9 \mathrm{~b}(1,3)$ & $2506 \mathrm{a}(625)$ & $70,1 \mathrm{a}(11,2)$ & $51,7 \mathrm{a}(10,7)$ \\
\multirow{3}{*}{ Guarea guidonia } & T0 & $7,0 \mathrm{a}(1,8)$ & $2120 \mathrm{a}(423)$ & $50,2 \mathrm{a}(13,1)$ & $32,8 \mathrm{a}(13,0)$ \\
& T2 & $3,9 \mathrm{~b}(1,2)$ & $1532 \mathrm{ab}(534)$ & $29,4 \mathrm{~b}(11,9)$ & $22,3 \mathrm{a}(10,8)$ \\
& T4 & $5,5 \mathrm{ab}(1,9)$ & $1442 \mathrm{~b}(430)$ & $43,5 \mathrm{ab}(9,2)$ & $21,6 \mathrm{a}(9,1)$ \\
\hline
\end{tabular}

$\mathrm{T} 0=$ control; T2 and T4 treatment with two or four plants of $U$. brizantha per pot, respectively. For each species, means followed by the same letter in the column do not differ by Tukey test $(\mathrm{P} \geq 0,95)$. Number in parentheses refers to the standard deviation.

Significant differences were observed for C. trichotoma with respect to the effect of coexistence on the accumulation of nutrients in the leaves (Table 2). When compared to the control, potassium levels were higher in treatments with the presence of $U$. brizantha (75\%). For magnesium, the accumulation found in plants of the control treatment were superior to those found in T2 plants (31\%). G. guidonia plants were not significantly affected between treatments.

Tabela 2: Teor $\left(\mathrm{g} \mathrm{kg}^{-1}\right)$ foliar de nutrientes de duas espécies arbóreas na ausência e após 84 dias de convivência com duas densidades de Urochloa brizantha, em condições de vasos

Table 2: Leaf contents ( $\mathrm{g} \mathrm{kg-1)}$ of nutrients in two tree species in the absence and after 84 days of coexistence with Urochloa brizantha at two densities, under pot conditions

\begin{tabular}{lcccccc}
\hline Tree species & Treat. & Nitrogen & Phosphorus & Potassium & Calcium & Magnesium \\
\hline \multirow{3}{*}{ Cordia trichotoma } & T0 & $24,7 \mathrm{a}(1,4)$ & $1,9 \mathrm{a}(0,2)$ & $6,3 \mathrm{~b}(0,8)$ & $31,6 \mathrm{a}(8,3)$ & $13,4 \mathrm{a}(1,2)$ \\
& T2 & $27,2 \mathrm{a}(1,9)$ & $2,6 \mathrm{a}(1,2)$ & $10,7 \mathrm{a}(2,8)$ & $28,9 \mathrm{a}(3,3)$ & $9,2 \mathrm{~b}(2,0)$ \\
& T4 & $24,5 \mathrm{a}(3,1)$ & $3,1 \mathrm{a}(1,7)$ & $11,0 \mathrm{a}(4,6)$ & $34,1 \mathrm{a}(4,1)$ & $9,8 \mathrm{~b}(2,4)$ \\
\hline \multirow{4}{*}{ Guarea Guidonia } & T0 & $22,7 \mathrm{a}(2,6)$ & $1,8 \mathrm{a}(0,6)$ & $8,4 \mathrm{a}(3,3)$ & $12,8 \mathrm{a}(1,8)$ & $3,1 \mathrm{a}(0,4)$ \\
& T2 & $22,1 \mathrm{a}(1,0)$ & $2,9 \mathrm{a}(0,4)$ & $10,9 \mathrm{a}(1,8)$ & $9,6 \mathrm{a}(1,8)$ & $2,6 \mathrm{a}(0,7)$ \\
& T4 & $21,5 \mathrm{a}(3,4)$ & $2,0 \mathrm{a}(0,9)$ & $12,5 \mathrm{a}(4,4)$ & $10,3 \mathrm{a}(2,9)$ & $2,4 \mathrm{a}(0,5)$ \\
\hline
\end{tabular}

$\mathrm{T} 0=$ control; $\mathrm{T} 2$ and T4 treatment with two or four plants of $U$. brizantha per pot, respectively. For each species, means followed by the same letter in the column do not differ by Tukey test $(\mathrm{P} \geq 0,95)$. Number in parentheses refers to the standard deviation.

\section{DISCUSSION}

It is believed that the absence of significant differences for the two tree species in relation to the increment in height after 84 days of coexistence with 2 and 4 plants of $U$. brizantha per pot occurred because of the short time of coexistence. Information from Portes et al. (2000) indicates that $U$. brizantha, depending on the edaphoclimatic conditions, is suitable for consumption by livestock from 90 and 150 days after planting with seedlings, that is, the time required for this plant to reach ideal conditions of adaptation in the field is longer than the observation period of the experiment. A study conducted by Santos et al. (2019a) demonstrates that the presence of 6 plants of $U$. brizantha per 18-L pot negatively affected the growth of four tree species of the five tested, at 180 days after sowing of $U$. brizantha. The absence of response, except for an increase in the collar diameter of Cordia trichotoma, is probably due to the relatively slow growth of the species, which is of late secondary successional stage according to Carvalho (2003). Therefore, in this short period evaluated, the presence or absence of $U$. brizantha did not result in significant difference. According to Lorenzi (2014), Guarea guidonia is a heliophyte species and considered to be relatively fast growing among tree species occurring in the Atlantic

FLORESTA, Curitiba, PR, v. 50, n. 4, p. 1725 - 1730, out/dez 2020.

Santana, J. E. S. et.al.

ISSN eletrônico 1982-4688

DOI: $10.5380 /$ rf.v50 i4. 60174 
Forest, indicating that it is more susceptible to competition with plants of the genus Urochloa, which are very competitive with native tree species according to Melotto et al. (2009) and Santos et al. (2019a).

Several studies have demonstrated the effect of reduction in the growth of tree species in competition with Urochloa species. Pereira et al. (2011) found a reduction in the growth of Corymbia citriodora, in coexistence with $U$. decumbens from 20 plants $\mathrm{m}^{-2}$. Similar results were obtained with Eucalyptus urophylla $\mathrm{x}$ E clone. grandis in competition with $U$. brizantha, from 22 plants $\mathrm{m}^{-2}$ (COLMANETTI et al., 2019) and Pinus elliottii with $U$. plantaginea and $U$. humidicola (PEREIRA et al., 2016). In studies with native tree species, Monquero et al. (2015) evaluated the effect of increased densities of $U$. decumbens on the growth of Senegalia polyphylla, Enterolobium contortisiliquum, Ceiba speciosa and Luehea divaricata and found that the presence of the competing species negatively affected the growth of these tree species even at the lowest density of two plants per pot. Santos et al. (2019b) observed that the coexistence with $U$. brizantha negatively affected the growth of Schinus terenbtifolius. All species of these studies are considered to be pioneers or early secondary (CARVALHO, 2003; LORENZI, 2014), which usually have higher growth potential than late secondary and climax ones, hence having lower growth in the presence of $U$. brizantha, different from Cordia trichotoma, which virtually did not show responses of growth, because it is early to late secondary, naturally having slow growth in the early stages of development. Another factor that may have contributed to the small significant responses of the plants of the two tree species of the present study is the relatively short time of coexistence. It was observed that in the first 15 days after the transplanting of $U$. brizantha plants, they practically did not grow because they were adapting to the environment, so the time of coexistence was below 70 days. In future studies, larger pots and longer time of coexistence are recommended, as occurred in the cited studies.

The absence of significant differences in the leaf contents of N, P and Ca of the two tree species probably occurred because the soil used is relatively rich in nutrients and $U$. brizantha did not reach its maximum vigor, which occurs from 90 to 150 days after planting the seedlings according to Portes et al. (2000). The relatively lower $\mathrm{K}$ content in Cordia trichotoma plants of the treatment without $U$. brizantha was not expected and no explanations were found in the literature for this result. Significantly lower mean $\mathrm{Mg}$ contents in plants of this tree species in coexistence probably occurred because $U$. brizantha plants were in full growth at the time of harvest of the experiment, as according to Vitti et al. (2006) $\mathrm{Mg}$ is important in enzymatic activation, being a co-factor of almost all phosphorylation enzymes, being fundamental in the processes of photosynthesis, respiration and reactions of synthesis of organic compounds. Thus, Cordia trichotoma, besides being a relatively slow-growth species, had lower Mg content in coexistence with $U$. brizantha plants.

\section{CONCLUSIONS}

Under the studied conditions, it was concluded that:

- After 84 days of coexistence, Urochloa brizantha practically did not affect the growth of Cordia trichotoma and for Guarea guidonia there were negative effects for most of the parameters evaluated.

- $\quad$ The coexistence with $U$. brizantha negatively affected only the average magnesium leaf content of Cordia trichotoma plants.

\section{ACKNOWLEDGMENTS}

To the Guandu River Hydrographic Basins Committee and the Paraíba do Sul River Basin Agency (AGEVAP) for their financial support and to Embrapa Agrobiology for providing the area for the study.

\section{REFERÊNCIAS}

BOX, G. E. P.; COX, D. R. An analysis of transformations. Journal of the Royal Statistical Society, London, V.26, n.2, p.211-252, 1964.

CARVALHO, P.E.R. Espécies arbóreas brasileiras. Brasília: Embrapa, 1039 p., 2003.

COLMANETTI, M. A. A.; BACCHA, A. L.; ALVES, P. L. C. A.; PAULA, R.C. Effect of increasing densities of Urochloa brizantha cv. Marandu on Eucalyptus urograndis initial development in silvopastoral system. Journal Forestry Research, v.30, n.2, p.537-543, 2019.

FONTE, S. J.; NESPER, M.; HEGGLIN, D.; VELÁSQUEZ, J. E.; RAMIREZ, B.; RAO, M. I.; BERNASCONI, S. M.; BÜNEMANN, E. K.; FROSSARD, E.; OBERSONB, A. Pasture degradation impacts soil phosphorus storage via changes to aggregate-associated soil organic matter in highly weathered tropical soils. Soil Biology and Biochemistry, Amesterdãn, v. 68, n. 1, p.150 - 157, 2014. 
HALING, R. E.; CAMPBELL, C. D.; TIGHE, M. K.; GUPPY, C. N. Effect of competition from a C 4 grass on the phosphorus response of a subtropical legume. Crop and Pasture Science, Melbourne, v. 64, n. 10, p. 985 - 992 , 2013.

LORENZI, H. Árvores brasileiras: manual de identificação e cultivo de plantas arbóreas nativas do Brasil. Nova Odessa: Editora Plantarum, 384 p., 2014.

MARCHI, S. R.; BELLÉ, J. R.; FOZ, C. H.; FERRI, J.; MARTINS, D. Weeds alter the establishment of Brachiaria brizantha cv. Marandu. Tropical Grasslands-Forrajes Tropicales, Cali, v.5, n.2, p.85 - 93, 2017.

MEDEIROS, W. N.; MELO, C.A. D.; TIBURCIO, R. A. S.; SILVA, G. S.; MACHADO, A. F. L.; SANTOS, L. D. T.; FERREIRA, F. A. Crescimento inicial e concentração de nutrientes em clones de Eucalyptus urophylla $\mathrm{x}$ Eucalyptus grandis sob interferência de plantas daninhas. Ciência Florestal, Santa Maria, v. 26, n. 1, p. 147 - 157 , 2016.

MELOTTO, A., NICODEMO, M.L., LAURA, V. A.; POTT, A., SILVA, V. P. sobrevivência e crescimento inicial em campo de espécies florestais nativas do Brasil Central indicadas para sistemas silvipastoris. Revista árvore, Viçosa, v. 33, n.3, p. 425-432, 2009.

MONQUERO, P. A.; ORZARI, I.; SILVA, P. V.; PENHA, A. S. Interference of weeds on seedlings of four neotropical tree species. Acta Scientiarum. Agronomy, Maringá, v. 37, n. 2, p. 219 - 232, 2015.

PEREIRA, M. R. R.; SOUZA, G. S. F.; SILVA, J. I. C.; MATINS, D. Plant densities of Urochloa decumbens in coexistence with Corymbia citriodora. Semina: Ciências Agrárias, Londrina, v. 32, n. 4, p. 1803 - $1812,2011$.

PEREIRA, M. R. R.; SOUZA, G. S. F.; SILVA JUNIOR, A. C.; MARTINS, D. Development of pine along with weed species. Revista de Ciências Agrárias: Amazonian Journal of Agricultural and Environmental Sciences, Belém v. 59, n. 2, p. 138-143, 2016.

PITELLI, R.A. Interferências de plantas daninhas em culturas agrícolas. In: Controle de Plantas Daninhas II. Informativo Agropecuário, v.11, n.129, p.16-27, 1985.

PORTES, T. A.; CARVALHO, S. I. C.; OLVEIRA, I.P.; KLUTHCOUSKI, J. Análise do crescimento de uma cultivar de braquiária em cultivo solteiro e consorciado com cereais. Pesquisa Agropecuária Brasileira, Brasília, v. 35, n.7, p. 1349-1358, 2000.

RESENDE, A. S.; LELES, P. S. S. O problema do controle de plantas daninhas na restauração florestal. In: RESENDE, A. S.; LELES, P. S. S (Org.). Controle de plantas daninhas em restauração florestal. Brasília: Ed. Embrapa, 2017, p. 13 - 27.

SANTOS, T. A.; RESENDE, A. S.; SILVA, F. F.; MORAES, L.F.D.; CHAER, G. M. Growth of tree species in coexistence with palisade grass Urochloa brizantha (Hochst. ex A. Rich.) stapf cv. Marandu. Planta Daninha, Viçosa, v.27, e019178812, 2019a.

SANTOS, T. A.; RESENDE, A. S.; SILVA, F. F.; MACHADO, A. F. L..; CHAER, G. M. Weed interference factors that affect the growth of an atlantic forest tree species. Bioscience Journal, Uberlândia, v.35, n.2, p.485494, 2019b.

SILVA, W.; SEDIYAMA, T.; SILVA, A. A.; CARDOSO, A. A. Consumption and water efficiency use index by Eucalyptus citriodora and E. grandis plants cultivated in pots containing soil with three water contents in the soil jointly with different Brachiaria brizantha populations. Floresta, Curitiba, v.34, n.3, p.325-335, 2004

SWANTON, C. J.; NKOA, R.; BLACKSHAW, R. E. experimental methods for crop-weed competition studies. Weed Science, Cambridge, v. 63, n. 1, p. 2 - 11, 2015.

TRENTIN, B. E.; ESTEVAN, D. A.; ROSSETTO, E. F. S.; GORENSTEIN, M. R.; BRIZOLA, G. P.; BECHARA, F. C. Restauração florestal na Mata Atlântica: passiva, nucleação e plantio de alta diversidade. Ciência Florestal, Santa Maria, v. 28, n. 1, p. 160-174, 2018.

VASIC, V.; KONSTANTINOVIC, B.; ORLOVIC, S. Weeds in Forestry and Possibilities of Their Control. In: PRICE, A. (Ed.) Weed Control. IntechOpen, 2012, p.147-170.

VITTI, G. C.; LIMA, E.; CICARONE, F. Cálcio, magnésio e enxofre. In: FERNANDES, M. S. (Ed.). Nutrição Mineral de Plantas.Viçosa: Sociedade Brasileira de Ciência do Solo, 2006, p. 299-326.

ZHONG, J.; ROBBETT, M.; POIRE, A.; PRESTON, J. C. Successive evolutionary steps drove Pooideae grasses from tropical to temperate regions. New Phytologist, New Jersey, v. 217, n. 2, p. 925 - 938, 2018.

FLORESTA, Curitiba, PR, v. 50, n. 4, p. 1725 - 1730, out/dez 2020.

Santana, J. E. S. et.al.

ISSN eletrônico 1982-4688

DOI: $10.5380 /$ rf.v50 i4. 60174 